\section{Effect of Phosphonate Applications, for Phytophthora Brown Rot Control, on 'Nadorcott' Mandarin External Fruit Quality}

\author{
Jan van Niekerk ${ }^{1,2,4}$, Charl Kotze ${ }^{1}$, Jade North ${ }^{1,3}$, \\ and Paul Cronje $\mathrm{e}^{1,3}$
}

AdDitional Index words. Phytophthora nicotianae, Phytophthora citrophthora, phytotoxic damage, ammonium phosphite, potassium phosphite

SUMMARY. Phosphonate foliar applications in the period before harvest are routinely used in citrus (Citrus sp.) production for the control of phytophthora brown rot (Phytophthora sp.) control. However, several grower reports indicated that these applications caused phytotoxic damage on 'Nadorcott' mandarin (Citrus reticulata hybrid) fruit. To investigate this, trials were conducted over two seasons (2016 and 2017 ) in two climatically different citrus production areas of South Africa. These trials consisted of ammonium and potassium phosphite foliar applications (at full dose or half dose) at green, color break, or full color stages of fruit development. At commercial harvest, fruit was sampled from the different treatments and the incidence of the phytotoxic damage was documented as both percentage incidence and a phytotoxic index (PI). Results indicated that, regardless of the type of phosphonate or dosage applied, phytotoxic damage was observed at harvest if foliar applications were carried out at color break or full color stage of fruit development. The same results were observed in the different climatic areas, although the mean percentage of damaged fruit varied between the areas. Based on these results it is recommended that skirt pruning be used to mitigate phytophthora brown rot on 'Nadorcott' mandarin fruit.

I n 2015, soft citrus (easy peelers) made up 9335 ha of the 68,000 ha within the South African citrus industry and is expected to significantly increase in the next 10 years. Within this group, late mandarin account for 6560 ha and has earned growers in 2015 a gross income of more than Rl1,000 (South African Rand) per tonne (South African Citrus Growers Association, 2016). Any disease that reduces yield and fruit quality can, therefore, greatly affect the profitability of this high value cultivar. In South Africa, brown rot of fruit is primarily incited by Phytophthora nicotianae or Phytophthora citrophthora (Meitz-Hopkins et al., 2013). It is a disease that can severely

The authors wish to thank Citrus Research International for funding of this research and the growers in Nelspruit (Indigo Farming), Riviersonderend and Riebeek-Kasteel (Suiderland Boerdery) for access to orchards for trial purposes.

${ }^{1}$ Citrus Research International, P.O. Box 28, Nelspruit 1200 , South Africa

${ }^{2}$ Citrus Research International, Department of Plant Pathology, University of Stellenbosch, Private Bag Xl, Matieland 7602, South Africa

${ }^{3}$ Citrus Research International, Department of Horticultural Science, University of Stellenbosch, Private Bag Xl, Matieland 7602, South Africa

${ }^{4}$ Corresponding author. E-mail: janvn@cri.co.za.

https://doi.org/10.21273/HORTTECH04022-18 reduce yield, fruit quality, or both in the orchard or in the postharvest cold chain (Adaskaveg et al., 2015; Montenegro et al., 2008). The disease is especially severe in areas where rainfall occurs during the late stages of fruit development and maturation (Adaskaveg et al., 2015).

Propagules of the aforementioned two pathogens are present in most orchard soils, from where they are readily splashed onto low-hanging citrus fruit. Sporangia form on the low-hanging fruit from where they can be splash-dispersed to fruit higher up on the tree (Graham et al., 1998; Timmer et al., 2000). Brown rot epidemics are further promoted by periods of prolonged wetness (more than $7 \mathrm{~d}$ ) and temperatures ranging between 23 and $32{ }^{\circ} \mathrm{C}$ (Graham et al., 1998; Timmer et al., 2000). These conditions are often prevalent in the cooler, winter rainfall citrus production areas of South Africa. 'Nadorcott' mandarin trees are known to bear heavily, resulting in branches bending down under the fruit weight, with numerous fruit often hanging close to the orchard floor (J. Joubert, personal communication). This characteristic and the fact that it matures during June-August, when rain often occurs in the aforementioned production areas, leads to the increased risk of severe brown rot epidemics occurring in mandarin orchards.

Properly timed foliar applications with phosphonates have been shown to be an excellent preventative control measure for brown rot of citrus fruit and root rot incited by Phytophthora species (Graham, 2011). For brown rot control in South Africa, it is specifically recommended to be applied 1 month or less before harvest (Van Zyl, 2017). Phosphonates are easily absorbed by the leaves of citrus trees from where they are translocated through the phloem to sinks, such as developing fruit and roots (Graham, 2011; Ouimette and Coffey, 1990). At the sites where they accumulate, they have been shown to have a direct fungistatic effect on invading pathogens and activating the plant's own defense mechanisms (Afek and Sztejnberg, 1988, 1989; Fenn and Coffey, 1984, 1985; Smillie et al., 1989).

This direct and indirect control action combined with a maximum preharvest interval of $28 \mathrm{~d}$ makes late-season phosphonate applications an attractive option for citrus growers who are expecting rain close to harvest that could trigger a brown rot epidemic incited by $P$. nicotianae (warmer production areas) or $P$. citrophthora (cooler production areas) (Hardman and Hattingh, 2016). However, an increasing number of reports were made by growers in cooler, winter rainfall, production

\begin{tabular}{lllc}
\hline $\begin{array}{l}\text { Units } \\
\text { To convert U.S. to SI, } \\
\text { multiply by }\end{array}$ & U.S. unit & SI unit & $\begin{array}{l}\text { To convert SI to U.S., } \\
\text { multiply by }\end{array}$ \\
\hline 0.4047 & acre $(\mathrm{s})$ & ha & 2.4711 \\
3.7854 & gal & $\mathrm{L}$ & 0.2642 \\
0.001 & $\mathrm{ppm}$ & $\mathrm{g} \cdot \mathrm{L}^{-1}$ & 1000 \\
0.1 & $\mathrm{ppm}$ & $\mathrm{mL} / 100 \mathrm{~L}$ & 10 \\
0.9072 & ton $(\mathrm{s})$ & tonne $(\mathrm{s})$ & 1.1023 \\
$\left({ }^{\circ} \mathrm{F}-32\right) \div 1.8$ & ${ }^{\circ} \mathrm{F}$ & ${ }^{\circ} \mathrm{C}$ & $\left({ }^{\circ} \mathrm{C} \times 1.8\right)+32$
\end{tabular}


areas of South Africa that they are experiencing phytotoxic damage to mandarin fruit when they applied phosphonates at late fruit developmental stages, when color development is advanced. As this was the first of the reports of such damage on mandarin fruit, further investigation was warranted.

Le Roux (2000) reported that foliar sprays of phosphonates can cause phytotoxic damage to citrus leaves and rapidly developing fruit in the late season if the application rates are high, as well as if spraying is carried out at high ambient temperatures or if the treated trees are under drought stress. However, investigation of the reports from growers indicated that label recommendations regarding application conditions, timing and dosages were strictly adhered to, thereby, eliminating these as possible causes for the observed damage. However, Walker (1989) reported incidences of phytotoxic damage to leaves of small, nonfruiting mandarin trees treated with foliar phosphonate sprays and that the damage increased with increasing dosages. Furthermore, Manrakhan et al. (2015) found similar damage on 'Nadorcott' mandarin fruit when spinosad-based bait sprays were applied for the control of fruit flies (Ceratitis sp.). In this study, it was found that damage only occurred on fruit that were at the immature green and color break stage. These findings, therefore, indicate a possible change in susceptibly due to changes occurring during maturation of the rind.

As stated previously, phosphonate foliar applications in the period close to harvest are highly effective for the control of phytophthora brown rot (Graham, 2011). The aim of this study was to verify and quantify any possible phytotoxic damage to 'Nadorcott' mandarin fruit caused by phosphonate foliar applications, aimed at phytophthora brown rot control, at various fruit developmental stages, over two seasons (2016 and 2017) in two orchards, located in climatically diverse production areas.

\section{Materials and methods Cultivar and trial sites}

'Nadorcott' mandarin was used as all reports of phosphonate phytotoxic damage occurred on fruit of this cultivar. It furthermore makes up the majority (38\%) of the mandarin plantings in South Africa (South African Citrus Growers Association, 2016). Different trial sites were selected for this study to determine whether climatic conditions; i.e., subtropical (summer rainfall) or Mediterranean (winter rainfall) during fruit development played any role in the fruit's susceptibility to phytotoxic damage or if it was related to this specific cultivar.

The first trial site (2016 and 2017) was located outside Nelspruit in the Mpumalanga Province of South Africa, which is characterized by little or no rain during the 'Nadorcott' harvest period in winter. The trees in this orchard were 10 years old and planted on Carrizo citrange (Citrus sinensis $\times$ Poncirus trifoliata) rootstock.

In 2016, the second trial site was located at Riviersonderend in the Western Cape Province of South Africa. This area is prone to rain, and, therefore, at a high risk for brown rot development, during the 'Nadorcott' harvest period. This orchard was 12 years old and planted on Carrizo citrange rootstock. The second trial site in 2017 had similar climatic characteristics to Riviersonderend but was near Riebeek-Kasteel and was a 10-year-old orchard on Carrizo citrange rootstock. The switch in the trial site was necessitated because of a severe drought experienced at Riviersonderend in 2017. This could have led to trial trees being stressed, which could have adversely affected results obtained.

\section{Treatments}

In the first season (2016), potassium phosphite $\left[555 \mathrm{~g} \cdot \mathrm{L}^{-1}\right.$ a.i. (350 $\mathrm{g} \cdot \mathrm{L}^{-1}$ phosphorous acid equivalent) (Fighter; Agchem, Pretoria, South Africa)] and ammonium phosphite [386 g. $\mathrm{L}^{-1}$ a.i. (300 g. $\mathrm{L}^{-1}$ phosphorous acid equivalent) (Brilliant; Arysta LifeScience, Umhlanga, South Africa)] were applied according to label rates to treated trees. In the case of the potassium phosphite, it was $570 \mathrm{~mL} /$ $100 \mathrm{~L}$ water and for ammonium phosphite the rate was $666 \mathrm{~mL} / 100 \mathrm{~L}$ water with trees sprayed from both sides to just before the point of runoff, $\approx 10 \mathrm{~L}$ per tree. A motorized backpack mist blower (Stihl SR 420; Andreas Stihl, Pietermaritzburg, South Africa) was used for all applications to only spray single trees. The application times coincided with the immature green, color break and full color stages of fruit development. Treatments were the same at both sites although a single buffer tree was left between treatments.

In the second season (2017), the treatments at both sites were the same as applied in 2016. However, two additional treatments were added. Apart from the label dosages, both potassium phosphite and ammonium phosphite were also applied at half the recommended dosages; i.e., 285 $\mathrm{mL} / 100 \mathrm{~L}$ water for potassium phosphite and $333 \mathrm{~mL} / 100 \mathrm{~L}$ water for ammonium phosphite. These additional treatments were replicated in the same manner as the full rate treatments.

\section{Experimental layout}

In 2016, the experimental layout at both sites was a randomized block split plot design, with 18 trees within each block. The main plot factor was chemical treatment (potassium phosphite, ammonium phosphite and unsprayed control) replicated in three blocks and the subplot factor was application time (different fruit color development stages - immature green, color break, and full color stage). An experimental unit consisted of 40 fruit that were harvested randomly at commercial maturity from the two trees of each treatment $\times$ application time combination within each block replication.

The 2017 layout was the same except for two chemical treatments (half dosages for potassium and ammonium phosphite) that were added to the main plot.

Evaluation of PHYTOTOXICITY. The incidence of the phytotoxic damage was documented as both percentage incidence and a PI for each group of 40 fruit. This dual recording resulted in a better understanding of not only the incidence of damage per treatment, as expressed by mean percentage damaged fruit, but also the severity of the damage on the individual fruit as expressed as an index.

In the laboratory, the fruit were evaluated for phytotoxic damage according to a 0 to 3 index which was quantified as a rating; 0 being fruit with no damage, rating 1 fruit with $<10 \%$ of fruit surface damaged, rating 2 fruit having $11 \%$ to $30 \%$ 
surface damaged, and a rating 3 where fruit with $>30 \%$ of the fruit surface displayed damage.

\section{PI $=\Sigma[$ rind damage severity $(0-3)$ number of fruit within each class] /total number of fruit.}

At each application time, a sample of 20 fruit were collected. The fruit rind color of these fruit was measured, to determine the fruit color at the different application times and to indicate the change in rind color development between application times. The measurements were carried out with a chroma meter (CR-400; Konica Minolta Sensing, Osaka, Japan) on the sun-exposed side of each fruit and expressed by the Hunter $a / b$ ratio (Fig. 1).

Statistical anAlysis. Data were (ANOVA) according to the experimental design using SAS (version 9.3; SAS Institute, Cary, NC). Experimental results from the two sites were also combined after confirmation of site homogeneity of variance. Where site variances were unequal (2017 data) a weighted ANOVA icant difference was calculated at a $5 \%$ significance level to compare means.

\section{Results \\ Phytotoxic damage symptoms}

At trial evaluation, in both years, similar symptoms of phytotoxic damage were observed on fruit sprayed

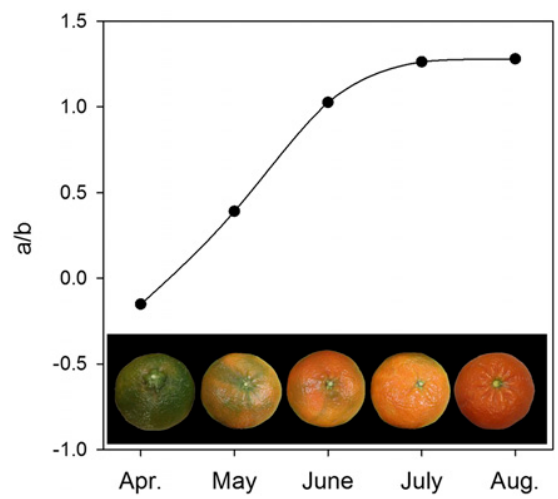

Fig. 1. Graphic representations of the color change in the 'Nadorcott' mandarin fruit at the various treatment application dates between April and August. Color change is expressed as the Hunter $a / b$ ratio. subjected to analysis of variance was conducted. Fisher's least signif- with either potassium or ammonium phosphite. On fruit that was sprayed with these chemicals at color break phase, the phytotoxic damage on the fruit rind manifested as dark brown lesions of variable sizes (Fig. 2A and B). These lesions consisted of an area where the flavedo was damaged to such an extent that the white, underlying albedo was exposed. A green margin was furthermore observed to occur around the lesions (Fig. 2A and B).

On fruit that was sprayed with the aforementioned chemicals at the full color developmental phase (Fig. $2 \mathrm{C}$ and $\mathrm{D})$, much more severe damage was observed of the fruit rind compared with fruit sprayed at the green stage (not shown). Again, the lesions were of variable sizes but had the appearance of dark brown, sunken areas, where the flavedo was damaged and the underlying albedo had a reddish brown color (Fig. 2C and D).

Percentage incidence AND SEVERITY OF PHYTOTOXIC DAMAGE. Analysis of variance of the mean percentage fruit with phytotoxic damage in 2016 indicated a significant $[P<$ 0.001 (ANOVA not shown)] area $x$
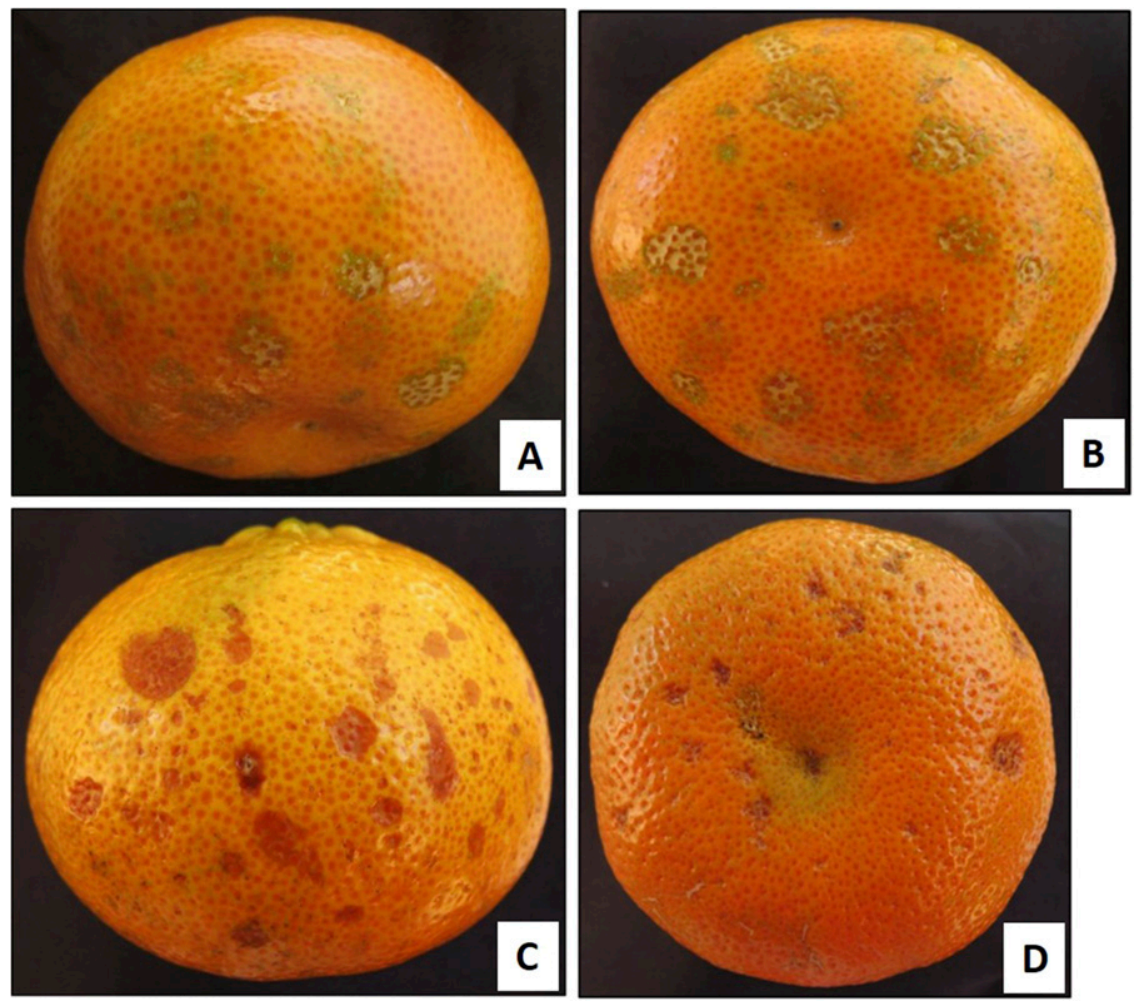

Fig. 2. Phytotoxic damage caused on the rind of 'Nadorcott' mandarin fruit at harvest after potassium or ammonium phosphite applications (full or half dose) at color break $(\mathrm{A}, \mathrm{B})$ or full color $(\mathrm{C}, \mathrm{D})$ stage of fruit development. age had occurred (Table 1 ). treatment $x$ color phase interaction. At both trial sites, no damaged fruit was observed at harvest when potassium phosphite was sprayed at the green stage (Table 1; Fig. 1). Although not significantly higher, compared with potassium phosphite $0.2 \%$ damaged fruit was observed at harvest, at both trial sites, on fruit sprayed with ammonium phosphite at the green stage. However, this was not significantly more than the unsprayed control (Table 1). For this application, the average PI on the $0.2 \%$ damaged fruit was less than 0.05 , indicating that very slight dam-

However, for fruit sprayed at the color break stage, significant differences compared with the control were observed between the trial sites, irrespective of the chemical applied ( $\mathrm{Ta}$ ble 1). At the Riviersonderend trial site, no fruit were damaged by either of the chemicals when applied at the color break stage. Compared with this, at the Nelspruit trial site, a mean percentage of $44.2 \%$ was damaged by potassium phosphite applications at color break stage. The average PI of this fruit was 1.23 (Table 1 ). A mean 
percentage of $40 \%$ was damaged by ammonium phosphite applications at the same stage resulting in an average PI of 1.12 (Table 1). For the respective chemicals these mean percentages were statistically similar but significantly more than the unsprayed treatment where no damaged fruit was observed (Table 1).

The results obtained with full color applications again indicated significant differences between the areas and the two chemicals tested. At the Riviersonderend trial site $100.0 \%$ of fruit sprayed with potassium phosphite at this stage showed damage with a high PI of 2.36 (Table 1 ). This application in Nelspruit caused significantly less damage at $85.0 \%$ although the PI of 2.33 did not differ much from that observed at Riviersonderend (Table 1). The ammonium phosphite applications at the two sites resulted in statistically similar incidences of $93.3 \%$ in Riviersonderend and $95.0 \%$ in Nelspruit. Furthermore, the PI of this application at the different sites were similar at 2.69 and 2.58 , respectively, and not in all cases notably more than the unsprayed control (Table 1).

Analysis of the 2017 data indicated only a significant $(P<0.001)$ treatment $x$ color phase interaction (ANOVA not shown). In terms of the incidence of damage observed, ammonium phosphite applications at half dose during the green phase, caused $1.7 \%$ fruit to show phytotoxic damage at harvest. However, the PI of this fruit was only 0.03 (Table 2) and the percentage damaged fruit was not significantly higher than the other chemical treatments or the unsprayed control where no damage was observed (Table 2).

At the color break phase, the potassium phosphite and ammonium phosphite applications, at full and half dosages, caused phytotoxic damage that was significantly more than the unsprayed control (Table 2). The full dose potassium phosphite application caused a mean percentage of damaged fruit of $59.2 \%$ that was, although not significant, more than potassium phosphite applied at half dose $(40.0 \%)$ and ammonium phosphite (39.2\%).
The application with half dose ammonium phosphite caused a mean percentage of damaged fruit of $21.7 \%$ that was statistically similar to the other treatments, except the full dose potassium phosphite application (Table 2). In terms of the severity, the most severe damage (PI 1.07) was also caused by the fulldose potassium phosphite application. This was similar to the half-dose potassium phosphite application (PI 0.70) and full-dose ammonium phosphite application (PI 0.70). The latter two treatments did, however, not cause notably more severe damage than the half-dose ammonium phosphite application [PI 0.33 (Table 2)].

Significant increased incidence of damage occurred in fruit in all treatments when applied at the full color stage (Table 2 ). The highest incidence of damage was seen with the full dose of potassium phosphite applications; i.e., $63.3 \%$ and PI of 1.11. This percentage damage was statistically similar to the full-dose ammonium phosphite applications $(52.5 \%)$ with a PI of 1.11 , which

Table 1. Mean percentage damaged fruit observed at harvest after potassium and ammonium phosphite treatments applied at the green, color break, and full color stages of 'Nadorcott' mandarin fruit development in 2016 at the Riviersonderend and Nelspruit, South Africa, trial sites. Average phytotoxic index (PI) values are presented in parenthesis.

\begin{tabular}{|c|c|c|c|c|c|c|}
\hline \multirow[b]{4}{*}{ Treatment } & \multicolumn{3}{|c|}{ Riviersonderend } & \multicolumn{3}{|c|}{ Nelspruit } \\
\hline & \multicolumn{6}{|c|}{ Color phase } \\
\hline & Green & Color break & Full color & Green & Color break & Full color \\
\hline & \multicolumn{6}{|c|}{ Mean damaged fruit (\%) (Avg. PI $)^{\mathrm{z}}$} \\
\hline Potassium phosphite & $0.0 \mathrm{e}^{\mathrm{y}}(0.00)$ & $0.0 \mathrm{e}(0.00)$ & $100 \mathrm{a}(2.36)$ & $0.0 \mathrm{e}(0.00)$ & $44.2 \mathrm{~d}(1.23)$ & $85 \mathrm{c}(2.33)$ \\
\hline Ammonium phosphite & $0.2 \mathrm{e}(0.00)$ & 0.0 e $(0.00)$ & $93.3 \mathrm{~b}(2.70)$ & $0.2 \mathrm{e}(0.00)$ & $40 \mathrm{~d}(1.12)$ & $95 \mathrm{ab}(2.58)$ \\
\hline Unsprayed & $0.0 \mathrm{e}(0.00)$ & $0.0 \mathrm{e}(0.00)$ & 0.0 e $(0.00)$ & 0.0 e $(0.00)$ & 0.0 e $(0.00)$ & 0.0 e $(0.00)$ \\
\hline
\end{tabular}

${ }^{\mathrm{z}}$ Average phytotoxic rating calculated per experimental unit of 40 fruit.

${ }^{\mathrm{y}}$ Means with a different letter within a column differ significantly at the $5 \%$ level via Fisher's least significant difference (LSD).

Table 2. Mean percentage damaged fruit observed at harvest caused by full- and half-dose potassium and ammonium phosphite treatments applied at the green, color break, and full color stages of 'Nadorcott' mandarin fruit development in 2017 at the Riebeek-Kasteel and Nelspruit, South Africa, trial sites. Average phytotoxic index (PI) values are presented in parenthesis.

\begin{tabular}{|c|c|c|c|}
\hline \multirow[b]{3}{*}{ Treatment } & \multicolumn{3}{|c|}{ Color phase } \\
\hline & Green & Color break & Full color \\
\hline & \multicolumn{3}{|c|}{ Mean damaged fruit (\%) $(\text { Avg. PI })^{\mathrm{z}}$} \\
\hline Potassium phosphite (half dose) & $0.00 \mathrm{f}(0.00)$ & $40.00 \mathrm{bcd}(0.70)$ & 20.83 de $(0.37)$ \\
\hline Ammonium phosphite (full dose) & $0.00 \mathrm{f}(0.00)$ & 39.17 bcd $(0.70)$ & $52.50 \mathrm{ab}(0.92)$ \\
\hline Ammonium phosphite (half dose) & 1.67 ef $(0.03)$ & $21.67 \mathrm{cde}(0.33)$ & $41.67 \mathrm{bc}(0.85)$ \\
\hline
\end{tabular}

${ }^{\mathrm{z}}$ Average phytotoxic rating calculated per experimental unit of 40 fruit.

${ }^{\mathrm{y}}$ Means with a different letter within a column differ significantly at the $5 \%$ level via Fisher's least significant difference (LSD). 
was markedly higher than the halfdose treatments or untreated control treatment (Table 2). The half-dose ammonium phosphite application had an incidence of $41.7 \%$ damaged fruit with a PI of 0.85 . The half-dose potassium phosphite application at color break caused the least amount of damage with an incidence of $20.8 \%$ and PI of 0.37 , both values significantly the lowest (Table 2).

\section{Discussion}

Results from the present study, carried out over 2 years in climatically diverse production areas, clearly indicated that irrespective of application dosage (full or half), phytotoxic damage of 'Nadorcott' mandarin fruit occurred when potassium or ammonium phosphite foliar applications were carried out at either the color break or full color fruit developmental stage. This then also constitutes the first report of phytotoxic damage by phosphonate foliar spray applications on 'Nadorcott' mandarin fruit.

Phytotoxic damage of mandarin leaves caused by phosphonate applications was previously reported by Walker (1989). Le Roux (2000) furthermore reported that when phosphonate foliar applications are carried out at high dosages, high ambient temperatures, or when trees are under stress, phytotoxic damage can occur. However, phosphonates have been used for many years on other cultivars without causing phytotoxic damage of fruit. Manrakhan et al. (2015) did report phytotoxic damage of 'Nadorcott' mandarin fruit by certain fruit fly bait sprays. By contrast to the present study, they reported that damage only occurred when applications were carried out on fruit at the immature green or color break stage of fruit development. These results indicate a possible change in the 'Nadorcott' mandarin rind biochemical composition during the rind maturation, which resulted in such a dramatic change in sensitivity to a chemical.

Even though the mechanism of the phytotoxic damage differs completely, the observed symptom development in the present study resembled to some extent the physiological rind breakdown seen in 'Navelate' sweet orange [C. sinensis (Agustí et al., 2001)]. The rind breakdown symptoms were described as sunken, colorless areas that over time develop into reddish brown areas. However, unlike rind breakdown, the phytotoxic lesions observed were not randomly distributed on the fruit surface but were mostly on the exposed side or at the bottom of the fruit due to droplet runoff. This type of symptom development was especially seen with applications carried out at full color stage (Figs. 1 and 2C, D). It is suspected that the lesion development after cellular collapse, after phosphonate foliar applications follows the same progression in development of brown discoloration as during rind breakdown. Degradation of cells combined with enzymatic oxidation of the phenolic rich vacuolar contents was regarded as the cause of the dark brown areas observed during rind breakdown (Agustí et al., 2001). Development of rind pitting in 'Encore' mandarin fruit and oleocellosis in 'Washington' navel oranges ( $C$. sinensis) has been attributed to the release of phytotoxic rind oils from oil cells in the flavedo that were damaged by environmental or mechanical damage (Knight et al., 2002; Medeira et al., 1999).

The efficacy of phosphonate applications as preventative measures for the control of root rot and brown rot on fruit incited by Phytophthora species was attributed to it being easily absorbed by the leaves of citrus trees from where it gets translocated in the phloem (Graham, 2011; Ouimette and Coffey, 1990). Absorption of phosphonates by fruit could potentially also occur as the citrus rind was described by Schneider (1968) as being a modified leaf with stomata remaining active during all stages of fruit development.

During ripening the fruit rind undergoes several changes that include color development through the breakdown of chlorophyll and synthesis of carotenoids (Iglesias et al., 2007) as well as carbohydrate composition and more importantly compositional changes of cuticular wax, the first barrier which would affect the uptake of a chemical into the flavedo cells (Albrigo, 1972; El-Otmani and Coggins, 1987; El-Otmani et al., 1987). In addition, and possibly more importantly, are the changes that occur in the epidermis where cracks develop as the fruit grows, while certain cell wall components such as cellulose and hemicellulose also get broken down that reduce firmness while ripening (Muramatsu et al., 1999). These changes potentially could make the fruit more susceptible not only to physical but also to chemical damage, as the mandarin fruit matures.

It is, therefore, possible that the phytotoxic damage of the rind by phosphonate applications as seen in this study was incited by one of two mechanisms. After application at either color break or full color stage, the phosphonates are easily absorbed into the rind where it can either cause direct damage to the flavedo damaging either the oil cells or adjacent tissues or both. Damage of the oil cells will release phytotoxic oils that in turn damages the susceptible underlying cells. This could lead to release and subsequent oxidation and browning of the vacuolar content. Alternatively, the phosphonates could directly damage the cells of the flavedo, leading to the release and oxidation of the vacuolar content.

It is of interest to note that during the first season (2016), significant differences in phytotoxic damage occurred between Riviersonderend and Nelspruit in both incidence (percentage damaged fruit) as well as severity (PI). No damage was observed in Riviersonderend whereas in Nelspruit the amount of damage ranged between $40 \%$ and $44.2 \%$ (Table 1 ). These variances could be attributed to differences in fruit maturation rates between the two areas, which could have influenced the rind susceptibility. A difference in fruit maturation rate between the two areas is furthermore supported by the trail evaluation in Riviersonderend taking place during July 2016 whereas in Nelspruit this was carried out 4 weeks earlier in June 2016.

Evident from the results obtained in this study is that phosphonate applications, regardless of production area climate, cannot be used as a means of brown rot control on late mandarin fruit from color break stage of fruit development until harvest. Other measures such as skirting of trees should, therefore, be employed to manage this disease in these cultivars. It is also still possible to use phosphonate foliar or trunk applications as part of a preventative management program for root rot 
incited by Phytophthora species, as these applications occur just after fruit set and during the immature green stage of fruit development (Le Roux, 2000).

\section{Literature cited}

Adaskaveg, J.E., W. Hao, and H. Förster. 2015. Postharvest strategies for managing phytophthora brown rot of citrus using potassium phosphite in combination with heat treatments. Plant Dis. 99:14771482 .

Afek, U. and A. Sztejnberg. 1988. Accumulation of scoparone, a phytoalexin associated with resistance of citrus to Phytophthora citrophthora. Phytopathology 78:1678-1682.

Afek, U. and A. Sztejnberg. 1989. Effects of fosetyl-Al and phosphorous acid on scoparone, a phytoalexin associated with resistance of citrus to Phytophthora citrophthora. Phytopathology 79:736-739.

Albrigo, L.G. 1972. Distribution of stomata and epicuticular wax on oranges as related to stem end rind breakdown and water loss. J. Amer. Soc. Hort. Sci. 97:220-223.

Agustí, M., V. Almela, M. Juan, F. Alférez, F.R. Tadeos, and L. Zacarías. 2001. Histological and physiological characterization of rind breakdown of 'Navelate' sweet orange. Ann. Bot. 88:415-422.

El-Otmani, M., M.L. Arpaia, and C.W. Coggins. 1987. Developmental and topo physical effects on the n-alkanes of Valencia orange fruit epicuticular wax. J. Agr. Food Chem. 35:4246.

El-Otmani, M. and C.W. Coggins. 1987. Fruit age and growth regulator effects on the quantity and structure of the epicuticular wax of 'Washington' navel orange fruit. J. Amer. Soc. Hort. Sci. 110:371378.

Fenn, M.E. and M.D. Coffey. 1984. Studies on the in vitro and in vivo antifungal activity of fosetyl-Al and phosphorous acid. Phytopathology 74: 606-611.
Fenn, M.E. and Coffey. 1985. Further evidence for the direct mode of action of fosetyl-Al and phosphorous acid. Phytopathology 75:1064-1068.

Graham, J.H. 2011. Phosphite for control of phytophthora diseases in citrus: Model for management of Phytophthora species on forest trees? N. Z. J. For. Sci. 41S:S49S56.

Graham, J.H., L.W. Timmer, D.L. Drouillard, and T.L. Peever. 1998. Characterization of Phytophthora sp. causing outbreaks of citrus brown rot in Florida. Phytopathology 88:724-729.

Hardman, P. and V. Hattingh. 2016. Recommended usage restrictions for plant protection products on Southern African export citrus. Dec. 2016. Citrus Research International, Nelspruit, South Africa.

Iglesias, D.J., M. Cercos, J.M. ColmeneroFlores, M.A. Naranjo, G. Rios, E. Carrere, O. Ruiz-Rivero, I. Lliso, R. Morillon, and F.R.M.T. Tadeo. 2007. Physiology of citrus fruiting. Braz. J. Plant Physiol. 19:333-362.

Knight, T.G., A. Klieber, and M. Sedgley. 2002. Structural basis of the rind disorder oleocellosis in Washington navel orange (Citrus sinensis L. Osbeck). Ann. Bot. 90:765-773.

Le Roux, H.F. 2000. Physiological interactions of phosphorous acid and control of root pathogens. Proc. Intl. Citricult. IX Congr. II:926-928.

Manrakhan, A., P.R. Stephen, and P.J.R. Cronje. 2015. Phytotoxic effect of GF$120 \mathrm{NF}$ fruit fly bait on fruit of mandarin (Citrus reticulata Blanco cv. Nadorcott): Influence of bait characteristics and fruit maturity stage. Crop Protection 78:4853.

Medeira, M.C., M.I. Maia, and R.F. Vitor. 1999. The first stages of pre-harvest 'peel pitting' development in 'Encore' mandarin. A histological and ultrastructural study. Ann. Bot. 83:667-673.
Meitz-Hopkins, J.C., M.C. Pretorius, C. F.J. Spies, L. Huisman, W.J. Botha, S.D. Langenhoven, and A. McLeod. 2013. Phytophthora species distribution in South African citrus production regions. Eur. J. Plant Pathol.

Montenegro, D., O. Aguín, C. Pintos, M.J. Sainz, and J.P. Mansilla. 2008. A selective PCR-based method for the identification of Phytophthora hibernalis Carne. Span. J. Agr. Res. 6:78-84.

Muramatsu, N., T. Takahara, T. Ogata, and K. Kojima. 1999. Changes in rind firmness and cell wall polysaccharides during citrus fruit development and maturation. HortScience 34:79-81.

Ouimette, D.G. and M.D. Coffey. 1990. Symplastic entry and phloem translocation of phosphonate. Pestic. Biochem. Physiol. 38:18-25.

Schneider, H. 1968. The anatomy of citrus, p. 1-85. In: H.J. Weber and L.D. Batchelor (eds.). The citrus industry. Univ. California Press, Los Angeles, CA.

Smillie, R., B.R. Grant, and D. Guest. 1989. The mode of action of phosphite: Evidence for both direct and indirect modes of action on three Phytophthora sp. in plants. Phytopathology 79:921-926.

South African Citrus Growers Association. 2016. Key industry statistics for citrus growers 2016. South African Citrus Grower's Assn., Hillcrest, South Africa.

Timmer, L.W., S.E. Zitko, T.R. Gottwald, and J.H. Graham. 2000. Phytophthora brown rot of citrus: Temperature and moisture effects on infection, sporangium production, and dispersal. Plant Dis. 84:157-163.

Van Zyl, K. 2017. The chemical control of plant diseases in South Africa. AVCASA, Halfway House, South Africa.

Walker, G.E. 1989. Phytotoxicity in mandarins caused by phosphorous acid. Austral. Plant Pathol. 18:57-59. 